CATALAN REVIEW

Catalan Review

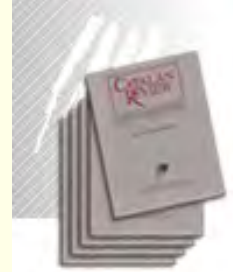

You are accessing the Digital Archive of the Catalan Review Journal.

By accessing and/or using this Digital Archive, you accept and agree to abide by the Terms and Conditions of Use available at http://www.nacs-

catalanstudies.org/catalan review.html

Catalan Review is the premier international scholarly journal devoted to all aspects of Catalan culture. By Catalan culture is understood all manifestations of intellectual and artistic life produced in the Catalan language or in the geographical areas where Catalan is spoken. Catalan Review has been in publication since 1986.
NORTH

AMERICAN

CATALAN

SOCIETY
Esteu accedint a l'Arxiu Digital del Catalan Review

A l' accedir i / o utilitzar aquest Arxiu Digital, vostè accepta i es compromet a complir els termes i condicions d'ús disponibles a http://www.nacs-

catalanstudies.org/catalan review.html

Catalan Review és la primera revista internacional dedicada a tots els aspectes de la cultura catalana. Per la cultura catalana s'entén totes les manifestacions de la vida intel lectual i artística produïda en llengua catalana o en les zones geogràfiques on es parla català. Catalan Review es publica des de 1986.

\title{
A Nineteenth-Century Traveler's Notes on the Minorcan Dialect and Customs of St. Augustine, Florida Philip D. Rasico
}

Catalan Review, Vol. I, number 2, (1986), p. 89-100 


\title{
A NINETEENTH-CENTURY TRAVELER'S NOTES ON THE MINORCAN DIALECT AND CUSTOMS OF ST. AUGUSTINE, FLORIDA
}

\author{
PHILIP D. RASICO
}

In the spring of 1843 the American author, William Cullen Bryant (1794-1878), embarked upon a series of travels through the southeastern United States which led him to the recently-acquired state of Florida an to the old Spanish city of St. Augustine. There he spent approximately two weeks, from April 8-24, where he enjoyed the agreeable climate and observed the inhabitants and customs of the city before continuing his journey northward. Bryant kept a diary or travelogue of his voyages which he published the same year in the New York Evening Post, and which he included eight years later in the section "A Tour in the Old South" of his volume Letters of a Traveller; or, Notes of Things Seen in Europe and America.'

An avid Hispanophile from his youth, Bryant showed a keen interest in the antiquity and Spanish ambiance of St. Augustine, and he was particularly fascinated by the language and character of an important segment of that city's population known collectively as Minorcans. The history of this group of people in Florida had its beginning three quarters of a century prior to Bryant's visit when, in 1768, some 1.255 natives of the Mediterranean were brought as indentured servants to British-held Florida by the Scottish physician turned land developer, Andrew Turnbull.

1 William Cullen Bryant, Letters of a Truteller; or, Notes of Things Secn in Europe and America, New York, G.P. Putnam, 1851. Bryant's two letters written from St. Augustine first appeared in the Evening Post on May 10 (letter dated April 12) and May 24 (letter dated April 24) of 1843. 
Turnbull previously had secured the title to an extensive tract of marshy land along the coast seventy-five miles south of St. Augustine at Mosquito Inlet. There he established a plantation, which he named New Smyrna, for the purpose of cultivating and exporting cash crops such as indigo, corn, hemp, cotton, rice, and grapes. Turnbull's group of colonists, the majority of whom consisted of Catalan-speaking Minorcans, although also among their numbers were various Italians, Greeks and Corsicans, were contracted to work on the plantation for a predetermined number of years at the end of which time they were to receive the land that they had cultivated as a reward for faithful service. However, both living and working conditions proved extremely harsh at New Smyrna, and 964 colonists, among them men, women and children, perished between the years 1768-1777. At the end of this period those who had been fortunate enough to survive famine, disease, and cruelty revolted and fled en masse to St. Augustine, where they obtained the protection of the British governor and received small plots of land north of the plaza near the old city gates.

Among the first descriptions of the physical characteristics and personal demeanor of the Minorcan colony are those given by William Cullen Bryant in his aforementioned Letters of a Traveller. He relates how he attended Palm Sunday services in the Catholic church of St. Augustine and there had occasion to observe the appearance of the congregation which consisted mainly of the descendants of Minorcans, Greeks, and Spaniards. Bryant des-

2 On the history of the Minorcan colony in Florida, including the Italians, Greeks and Corsicans, see E.P. Panagopoulos, New Smyrna: An Eighteentb Century Grick Odyssey, Gainesville, University of Florida Press, 1966; Kenneth H. Beeson, Jr., "Janas in British East Florida", Florida Historical Quartcrly, 44 (1965), 121-132; Jane Quinn, Minorcans in Floridu: Their History and Herilage, St. Augustine, Mission Press, 1975. 
cribed the more youthful of this group as having expressive countenances, builds which were slighter than those of Americans, and, in the case of the women, regular features with dark cheeks, brilliant eyes, and finely-formed hands. He subsequently added to this description that the Minorcans were "a mild, harmless race, of civil manners and abstemious habits".

Bryant also enjoys the distinction of having provided one of the earliest and most informative accounts of the condition of the Minorcan dialect in St. Augustine. ${ }^{4}$ In his letter written from that city on April 12,1843, he makes the following observations:

You meet in the streets with men of swarthy complexions and foreign physiognomy, and you hear them speaking to each other in a strange language. You are told that these are the remains of those who inhabited the country under the Spanish dominion, and that the dialect you have heard is that of the island of Minorca.

That the acoustic impression of the Minorcan's speech struck Bryant as being unfamiliar and somewhat exotic can be appreciated in his recollection of a second visit to the local Catholic church where he heard a man preaching in a language which he initially thought was Minorcan, since he was unable to make any sense of it. It was only later that Bryant learned from an old Spanish resident who had been in attendance that the discourse which they had heard had in fact been given in Spanish by a Frenchman who spoke this language with a heavy French accent, and that the na-

${ }^{3}$ Bryant, Letter of a Traveller, 104-105, 113.

${ }^{4}$ The earliest reference to the use of the Minorcan dialect in Florida is that which is found in a letter written by the Spanish governor, Vicente Manuel de Zéspedes, to José de Gálvez on October 20, 1784: "These Minorcans in general are an industrious people ... and they make use of the mother tongue" (translation by Joseph Byrne Lockey, East Florida 1783-1785: A File of Documents Assembled and Many of Them Translated, Berkeley, University of California Press, 1949, 285).

${ }^{5}$ Bryant, Letters of a Traveller, 102 , 
tive St. Augustinian himself had managed to comprehend only about an eighth of it."

A third and more specific reference to the Minorcan dialect of St. Augustine is discovered in another of Bryant's letters, dated April 24, in which he also mentions the Spanish language spoken in the city:

The Minorcan language, the dialect of Mahon, el Mathones, as they call it, is spoken by more than half of the inhabitants who remained here when the country was ceded to the United States, and all of them, I believe, speak Spanish besides. Their children, however, are growing up in disuse of these languages, and in another generation the last traces of the majestic speech of Castile, will have been effaced from a country which the Spaniards held for more than two hundred years. ${ }^{?}$

In addition to his remarks on the nature and linguistic habits of the Minorcans of St. Augustine, Bryant noted an old Minorcan custom which was still preserved by the local populace at the time of his visit. The tradition consisted of an Easter Vigil ritual in which groups of young men strolled from house to house tapping on shutters, playing musical instruments, and singing "in the Mahonese dialect" a hymn (Catalan goig) in honor of the Virgin. If the serenaders' visit was welcome, they received gifts of formatjades (a Minorcan cheese pastry), eggs and the like. Bryant transcribed and subsequently published the Minorcan song which, in his words, "was kindly taken down for me in writing by a native of St. Augustine", and in so doing he became responsible for the first example of the Catalan language to appear in print in North America." At the same time he also published a Spanish translation of

\footnotetext{
"Bryant, Lellers of a Traveller, 105.

7 Bryant, Letters of a Traveller, 113.

* Bryant, Letters of a Traveller, 114.

"Bryant, Letters of a Traveller, 114.
} 
the hymn "as taken down in writing from the mouth of one of the Mahonese, as they call themselves, a native of St. Augustine", although he warned that he did not hold himself accountable for the correctness of the Spanish in which it was rendered."

The old Minorcan hymn which Bryant recorded in 1843 is still heard today, albeit with numerous local variations, in several villages of the island of Minorca (es Castell, Migjorn Gran, and Sant Lluis, among others) where it is known as Deixem lo dol and popularly as the Cançó de les formatjades, but it has since ceased to be sung in St. Augustine. The American author's edition of the song is of significant linguistic interest in that it furnishes a general indication of the features of the Minorcan dialect as spoken in St. Augustine toward the middle of the nineteenth century. Furthermore, it also provides evidence of the characteristics of insular Minorcan from the second half of the preceding century, that is at the time of the arrival of Turnbull's colonists in Florida. It should be noted, however, that while Bryant seems to have had at least a competent command of the Spanish language, the Minorcan dialect of Catalan was completely unknown to him as he himself admits when recalling the language that he heard spoken in the streets and, especially, his second experience in the church." Consequently, Bryant represents a relatively good source for our knowledge of old St. Augustine Minorcan since, as he indicates, his transcription of the Deixem lo dol is that which was made for him by a St. Augustine resident who presumably was a Minorcan. Bryant's only modification of the language of the hymn appears limited to the rather inconsistent transcription of certain Minorcan sounds with spellings based upon English and to the use of an

10 Bryant, Letters of a Truteller, 116.

11 On Bryant's familiarity with Spanish, see Stanley T. Williams, The Spanish Background of American Litcrature, II, New Haven, Yale University Press, 1955, 122-151, 
occasional Spanish orthographic symbol. Regarding this system of transcription he states:

The letter $c$, which I have put in italics, represents the guttural French $e$, or perhaps more nearly the sound of $u$ in the word $b u$ [italics added]. The sh of our language is represented by sc followed by an $i$ or an $c$; the $g$ both hard and soft has the same sound as in our language. ${ }^{12}$

The following is Bryant's edition of the Deixem lo dol; although the lines of the hymn are not numbered in the original, they are so indicated here for subsequent reference: ${ }^{13}$

1 Disciarem lu dol

Cantarem anb' alagria,

Y n'arem a dá

Lis pascuas a Maria.

5 O Maria!

Sant Grabiel,

Qui portaba la anbasciada;

Des nostro rey del cel

Estarau vos preñada.

10 Ya omiliada,

Tu o vais aqui serventa,

Fia del Deu contenta,

Para fe lo que el vol.

Disciarem lu dol, etc.

15 Ya milla nit,

Pariguero vos regina;

A un Deu infinit,

Dintra una establina.

Y a millo dia,

12 Bryant, Lillers of a Trateller, 114.

"Bryant, Litlers of a Traveller, 114-120. 
20 Que los Angles van cantant

Pau y abondant

De la gloria de Deu sol.

Disciar'm lu dol, etc.

Ya Libalam,

25 Allá la terra santa,

Nus nat Jesus,

Anb' alagria tanta.

Infant petit

Que tot lu mon salvaria;

30 Y ningu y bastaria,

Nu mes un Deu tot sol.

Disciarem lu dol, etc.

Cuant d'Orien lus

Tres reys la stralla veran,

35 Deu omnipotent,

Adorá lo vingaran.

Un present inferan,

De mil encens y or,

A lu beneit Señó,

40 Que conesce cual se vol.

Disciarem lu dol, etc.

Tot fu gayant

Para cumplí lu prumas;

Y lu Esperit sant

45 De un angel fau gramas.

Gran foc ences,

Que crama lu curagia;

Deu nos da lenguagia,

Para fe lo que Deu vol.

50 Disciarem lu dol, etc.

Cuant trespasai

De quest mon nostra Señora, Al cel s'impugia 
Sun fil la matescia ori.

55 O emperadori,

Que del cel sou eligida!

Lu rósa florida,

Mé resplanden que un sol.

Disciars'm lu dol, etc.

60 Y el tercer giorn

Quc lesus resunta.,

Deu y Aboroma.

Que la mort triumfi.

De alli se ballá

65 Para perldri Lucife,

An tot a seu peudá,

Que de nostro ser el sol.

Disciarem lu dol, etc.

$\mathrm{C}^{\prime}$ set sois que vam cantant,

70 Regina celastial!

Dunus palu y alagria,

$\mathrm{Y}$ bonas festas tingau.

Yo vos dou sus bonas festas,

Danaus dinés de sus nous;

75 Sempre tarım lus mans llestas

Para recibí un grapat de ous.

Y el giorn de pascua florida

Alagramos y giuntament;

As qui e's mort par damos vida

80 Ya viú gloriosiment.

Aquesta casa está empedrada,

Bien halla que la empedró;

Sun amo de aquesta casa

Baldria duná un do.

85. Furmagiada o empanada,

Cucutta o flao;

Cual se vol cosa me grada,

Sol que no me digas que no.

Aquesta casa estí empedrada. 
Empedrada de cuatro vens;

Su amo de aquesta casa,

Es omo de compliment.

No es omo de compliment.

As one can readily discern, the hymn as recorded by Bryant suffers from a number of imperfections to the extent that it becomes nearly incomprehensible in parts. Some of these flaws are undoubtedly attributable to Bryant's lack of familiarity with the Catalan language in its Minorcan dialectal variety, although others may have originated with his native informant who, in all likelihood, had little if any formal knowledge of the language. ${ }^{1 .}$ It is remarkable, therefore, that the Minorcan hymn was preserved with such fidelity with respect to what must have been its original form. ${ }^{15}$

From a strictly linguistic perspective Bryant's edition of the Deixem lo dol exhibits various phonological and morphological features characteristic of insular Minorcan in the late eighteenth century, although also apparent are several Spanish lexical forms and even an entire phrase in this language.

Among the Minorcan features which appear in Bryant's transcription of the hymn are the following: ${ }^{16}$

${ }^{14}$ Bryant admits that his edition "has several corruptions, occasioned by the unskillfulness of the copyist" (Bryant, Letters of a Traveller, 114).

${ }^{15}$ An early twentieth-century version of the hymn from the island of Minorca appears in Francisco Camps y Mercadal, Folk-lore menoquín (de la pagesia), II, Mahón, M. Sintes Rotger, 1921, 55-59. Bryant's edition of the Deixem lo dol was reproduced in 1858 with numerous errors by George R. Fairbanks, History and Antiquities of tbe Cily of St. Augustine, Florida, New York, Charles B. Norton, 1858, 198-200. Other editions of the song were subsequently published, among them that of William W. Dewhurst who also provided an English translation of unknown authorship (William W. Dewhurst, The History of Saint Augustine, Florida, New York, G.P. Putnam's Sons, 1881, 165-168).

to The numbers which follow cited forms indicate the lines in which the 
1. Presence of the stressed mid-central vowel /á / ( Vulgar Latin /ẹ/ which is written $e$ and $a$ : disciarem $(1,14,23$, etc.; deixarem-dixarem) <LAXĀRE-

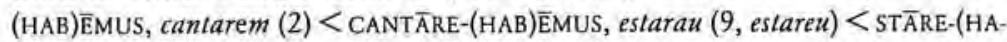
B) $\bar{E} T I S$, vais $(11 ;$ veis $)<$ VIDĒTISs, stralla $(34 ;$ estrella $)<$ STĒLLA, vingaran $(36$; vingucren) < VENĒRUNT, prumas (43, promés) < PROMISSU, gramas (45; tramés)<TRANSMISSU, quest $(52 ;$ aquest $)<$ ECCU.ISTU, danaus $(74 ;$ doneu-nos $)<$ DONĒTIS-NOS, dunus (71; deu-nos) < DĒTIS-NOS, tarem (75; tendrem-tindrem) < TENĒRE-(HAB)ĒMUS, alagramos $(73 ;$ alegrem-nos) < ALECREMUUS-NOS, aquesta $(81,83,89,91)<$ ECCU-ISTA.

2. Lowering of $a(/ \dot{o} /)$ to $a$ : fau (45: fou) <FưiT.

3. Confusion of unstressed $a$ and $e$ as [ $]$ ], here represented by $e, a$, and $u$ : alagria $(2,27$ : alegria $)<* A L E$ CRĨA, celastial $(70$; celestial) < CAELESTIĀLE, Libalam $(24$, Betlem) < BETHLEHEM, las pascuas (4; les pasqües) < (IL)LAS PASCHAS X PASCUAS, s'empugiá (53; s'empujä) < SE-"IMPÖDIĀVIT, lu rosa (57, la rosa) < (ï)LA RŌSA, lus mans $(75$; les mans) < (iL)LAS MANUS, sus nous $(74$, ses nous) $<$ IIPSAS NÖCES, sus bonas festas $(73$, ses bones festes) < İPAS BONAS FÉSTAS, llestas (755; llestes) < "LẺSTAS, pat $(79 ;$ per $)<$ PER. Bryant's transcription also indicates the pronunciation [ a ] in es $(79,92,93 ;$ és $)<$ ÉST.

4. Confluence of unstressed $o$ and $u$ as $u: l u \operatorname{dol}(1,14,23$, etc; $l o)<$ (IL)LU, and similarly lu mon (29), lu beneit Señó (39), lu prumas (43), lu Esperit sant (44), lu curagia $(47 ;$ lo coratge $)<$ (IL)LU *CORATICU; lus tres reys $(33 ;$ los tres reis) $<$ (IL)LOS, nu mes $(31$; només $)<$ NON-MAGIS, sun $(54,83,91$; son $)<$ sŨựM, duná $(79 ;$ donar $)<$ DO. NĀRE, cumplí $(43 ;$ complir $)<$ *COMPLİ̈E.

5. Monophthongization of final unstressed $e u$ to $o$ : pariguero (16; parigué$r e u)<$ "PARIVĪTIS.

6. Assimilation of final atonic $e([$ a $])$ to a preceding stressed back vowel: omo $(92,93$; cf. Min. bomo, Cat. bome $)<$ HOMINE, nostro $(8,67$; nostre $)<$ NÓSTRU.

7. Loss of word-final $r$ : dá $(3 ;$ dar $)<\mathrm{DA} R E, f e(13,49$; fer $)<$ FACĚRE, duná (79; donar) < DONĀRE, adotá (36; adorat $)<\mathrm{ADŌ} R \bar{A} R E$, Señó $(39$; senyor $)<$ SENIŌRE, cumpli $(43$; complir $)<$ "COMPLİRE. The effacement of $-r$ also appears to have occurred, as expected, in the combination mé resplanden ( 50 ; més resplendent) $<$ MAGls RESPLENDÉNTE, and curiously in the Castilianism recibi (76; Span. recibir) < RECIPẼRE. As in all Catalan dialects, $r$ is lost in the syllable-final sequence rs: dinés (74, dinets) $<$ DENARIOS.

latter occur in Bryant's edition of the Deixem lo dol. Modern Catalan forme are occasionally given for the purpose of clarification. For an overview of the characteristics of modern Minorcan, see Francesc de B. Moll, "Estudi fonètic i lexical del dialecte de Ciutadella", Randa, 8 (1979), 55-48; Joan Veny, Els parlars catalans (sintesi de dialectologia), Palma de Mallorca, Moll, 1982, 73-82. 
8. Loss of posttonic $l /(/ \mathrm{y} /)$ in fia $(12$; filla $)<$ FìlIA.

9. Raising of pretonic $e$ to $i$ in disciarem $(1,14,23$, etc.; Min. dixarem).

10. Retention of word-final $t$ after $n$ : cantant $(20)<$ CANTANDO, abondant (21; abundant) < ABUNDANTE, omnipotent (35) < OMNIPOTENTE, sant $(44)<$ SANC. TU, compliment $(92,93)<$ COMPLIMENTU, etc.

11. The interesting rendition of $/ j /$ as $/ l$ in milla nit $(15 ;$ mitjanit $)<$ MEDIA. NOCTE and in millo dia $(19 ;$ mig lo dia-migdia $)<$ MEDIU (ILLU) "DIA.

12. A single example of a second-person plural verb form in $-s$ (< anc. $-t s)$ : vais (II; Min. viis) < vidĒTIS.

13. Use of definite articles proceeding from the paradigms of Latin ILLE. and IPSE; lu dol (1, 14, 23, etc., lo dol), lu mon (29;lo món), el tercer giorn (60; cl tercer jorn), etc., ILLu; los Angles (20; los ängels), lus tres reys ( 34 ; los tres reis), etc. LILlos; la terra (25), la anbasciada (7; l'embaixada), la gloria (22; la glòria), etc. <ILLA; las pascuas (4; les pasqües), lus mans $(75 ;$ les mans), etc. $<1$ LLAS; ce set sois $(69 ;$; es set goigs) $<$ IPSOS, sus bonas festas $(73$; ses bones festes), sus nous $(74 ;$ ses nous) < IPSAS.

Finally, noteworthy too are the Castilianisms consisting of the entire line bien balla que la empedró (82) and the form cuatro (90; $\mathrm{ff}$. Cat, quatre), among others.

The prophetic statement which Bryant made concerning the imminent disappearance of Minorcan and Spanish in St. Augustine was by no means inaccurate, since today no native St. Augustinian of Minorcan or Spanish descent speaks the language of his or her ancestors. ${ }^{17}$ The loss of these languages as common media of daily verbal communication in St. Augustine seems to have been completed toward the end of the nineteenth century. Contrary to Bryant's prediction, however, some of the older residents of the city currently use a number of Minorcan and Spanish expressions which have become fossilized in their local variety of English. ${ }^{18}$ Nevertheless, few members of the younger generation

17 See Bryant, Lellers of a Traveller, 113.

is On the Minorcan and Spanish expressions which have survived in St. Augustine, see Philip D. Rasico, "Noticies històriques, lingüistiques i culturals dels menorquins floridencs", Randa, 15 (1983), 9-50; "The Spanish Lexical Base of Old St. Augustine Mabont'se: A Missing Link in Florida Spanish", Hispania (forthcoming). 
presently continue these linguistic traditions, and as William Cullen Bryant remarked nearly a century and a half ago, it is likely that the last traces of old St. Augustine Mabonese and Spanish will be lost within the next several decades.

PHILIP D. RASICO

VANDIERBILT UNIVIRSITY 